\title{
Regeneration after fire in campo rupestre: Short- and long-term vegetation dynamics ${ }^{\text {is }}$
}

\author{
Soizig Le Stradic ${ }^{\mathrm{a}, \mathrm{b}, \mathrm{c}, *}$, Pauline Hernandez ${ }^{\mathrm{a}}, \mathrm{G}$. Wilson Fernandes ${ }^{\mathrm{c}, \mathrm{d}}$, Elise Buisson ${ }^{\mathrm{a}}$ \\ a IMBE - Institut Méditerranéen de Biodiversité et d'Ecologie marine et continentale, Université d'Avignon et des Pays de Vaucluse, CNRS, IRD, Aix Marseille \\ University, Agroparc BP 61207, 84911, Avignon, France \\ b Laboratório de Fenologia, Departamento de Botânica/Instituto de Biociências, UNESP - Universidade Estadual Paulista, Rio Claro SP, CP 199, Brazil \\ ${ }^{\mathrm{c}}$ Ecologia Evolutiva e Biodiversidade, Universidade Federal de Minas Gerais, Belo Horizonte, MG, 30161-901, Brazil \\ ${ }^{\mathrm{d}}$ Department of Biology, Stanford University, Stanford, CA 94305, USA
}

\section{A R T I C L E I N F O}

\section{Article history:}

Received 25 July 2016

Received in revised form 4 December 2016

Accepted 5 December 2016

Edited by Fernando A.O. Silveira

Available online 28 December 2016

\section{Keywords:}

Biomass

Campo arenoso

Campo pedregoso

Rupestrian grasslands

Vegetation recovery

Wildfire

\begin{abstract}
A B S T R A C T
The Cerrado (Brazilian savanna) is the second largest biome in Brazil, covering $22 \%$ of the country, and campo rupestre is one of the most biodiverse ecosystem. Campo rupestre are extremely old mountaintop tropical ecosystems, composed of a mosaic of herbaceous, shrubland and savanna vegetation, generally located above $900 \mathrm{~m}$ above sea level characterized by shallow, acidic and nutrient-poor soils. In the context of increased land-use changes, effective conservation and management projects appear necessary to guarantee the conservation of these ecosystems. Although fire is a natural disturbance in campo rupestre, the effects of fire on vegetation dynamics remain poorly understood. Our objective was to assess the effects of fire on vegetation recovery and plant composition on both the short- and long-term in the main herbaceous vegetation types: the sandy and stony grasslands. We monitored plant community composition before and after a wildfire in order to assess the short-term vegetation recovery. Diachronic analyses of grasslands burnt at various dates were used to understand the effects of fire on the long-term vegetation dynamics. Our results highlighted a rapid recovery of campo rupestre vegetation after wildfires, suggesting a high adaptation to fire of plant communities. We did not find a significant variation in species richness of sandy grasslands according to time after fire, whereas higher species richness was observed in the recently burnt stony grasslands. No change in plant composition of campo rupestre in response to fire was highlighted, probably due to the high heterogeneity of this ecosystem. After fire, biomass gradually increased over time in both vegetation types. High biomass accumulation could lead to stronger fires. Further studies are necessary to understand the relationship between biomass accumulation and fire intensity in campo rupestre in order to set up adapted fire management strategies to conserve campo rupestre biodiversity.
\end{abstract}

(c) 2017 Elsevier GmbH. All rights reserved.

\section{Introduction}

The Brazilian Cerrado is the world's most species-rich savanna, which originally covered over 2 million $\mathrm{km}^{2}$ (Oliveira and Marquis, 2002). It is composed of a mosaic of ecosystems influenced by the interaction between climate, soil and fire (Oliveira and Marquis, 2002), ranging from the most open ecosystems, such as campo limpo

\footnotetext{
This article is part of a special issue entitled Plant life in campo rupestre: new lessons from an ancient biodiversity hotspot published at the journal FLORA 238C.

* Corresponding author at: IMBE - Institut Méditerranéen de Biodiversité et d'Ecologie marine et continentale, Université d'Avignon et des Pays de Vaucluse, CNRS, IRD, Aix Marseille Univ, Agroparc BP 61207, 84911, Avignon, France.

E-mail address: soizig.lestradic@gmail.com (S. Le Stradic).
}

grasslands, to ecosystems that show higher tree density, i.e. cerradão woodlands (Coutinho, 1978). The Cerrado has already lost ca. $50 \%$ of its area to soybean and maize plantation and to cattle raising (Carvalho et al., 2009; Fernandes, 2016), but only $2.85 \%$ of its total surface is located in fully protected conservation units (Bustamante, 2015). The protection of the remaining land therefore appears as a high conservation priority (Bitencourt et al., 2016; Mittermeier et al., 2011).

In savanna ecosystems, fire is a common endogenous disturbance (sensu McIntyre and Hobbs, 1999), i.e. disturbances to which the system has been exposed repeatedly through evolutionary time and that can maintain the biodiversity under an appropriate regime (Bond et al., 2003; Hoffmann et al., 2012; Mistry, 2000; Ratnam et al., 2011; Sankaran et al., 2005). In such fire-prone environments, plants species may present adaptive strategies that can improve 
Table 1

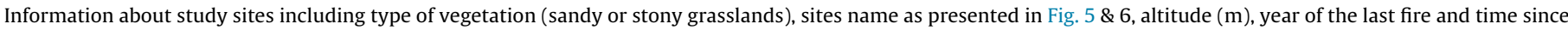

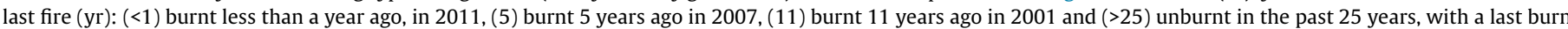
dated at least in 1987. * indicates the two sites which were followed more precisely before (February, 2009) and after the fire (October 2011 and January 2012).

\begin{tabular}{|c|c|c|c|c|c|c|c|}
\hline \multicolumn{4}{|c|}{ Sandy grasslands } & \multicolumn{4}{|c|}{ Stony grasslands } \\
\hline Site name & Altitude (m) & $\begin{array}{l}\text { Year of the } \\
\text { last fire }\end{array}$ & $\begin{array}{l}\text { Time since last } \\
\text { fire (yr) }\end{array}$ & Site name & Altitude (m) & $\begin{array}{l}\text { Year of the last } \\
\text { fire }\end{array}$ & $\begin{array}{l}\text { Time since last } \\
\text { fire }(\mathrm{yr})\end{array}$ \\
\hline Sa-A & 1299 & 2011 & $<1$ & St-A & 1313 & 2011 & $<1$ \\
\hline $\mathrm{Sa}-\mathrm{C}^{*}$ & 1178 & 2011 & $<1$ & St- $C^{*}$ & 1174 & 2011 & $<1$ \\
\hline Sa-D & 1232 & 2011 & $<1$ & St $-\mathrm{D}$ & 1220 & 2011 & $<1$ \\
\hline $\mathrm{Sa}-\mathrm{B}$ & 1299 & 2007 & 5 & St $-B$ & 1313 & 2007 & 5 \\
\hline $\mathrm{Sa}-\mathrm{F}$ & 1337 & 2007 & 5 & St $-\mathrm{F}$ & 1335 & 2007 & 5 \\
\hline $\mathrm{Sa}-\mathrm{L}$ & 1362 & 2007 & 5 & $\mathrm{St}-\mathrm{L}$ & 1353 & 2007 & 5 \\
\hline $\mathrm{Sa}-\mathrm{G}$ & 1402 & 2001 & 11 & St $-\mathrm{G}$ & 1403 & 2001 & 11 \\
\hline $\mathrm{Sa}-\mathrm{H}$ & 1417 & 2001 & 11 & $\mathrm{St}-\mathrm{H}$ & 1419 & 2001 & 11 \\
\hline $\mathrm{Sa}-\mathrm{I}$ & 1347 & 2001 & 11 & St $-\mathrm{I}$ & 1348 & 2001 & 11 \\
\hline $\mathrm{Sa}-\mathrm{E}$ & 1106 & 1987 & $>25$ & St $-E$ & 1109 & 1987 & $>25$ \\
\hline $\mathrm{Sa}-\mathrm{J}$ & 1284 & 1987 & $>25$ & St $-\mathrm{J}$ & 1288 & 1987 & $>25$ \\
\hline Sa $-K$ & 1303 & 1987 & $>25$ & $\mathrm{St}-\mathrm{K}$ & 1295 & 1987 & $>25$ \\
\hline
\end{tabular}

Table 2



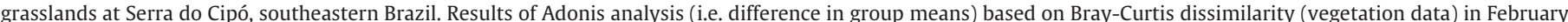
2009, October 2011 and January 2012)

\begin{tabular}{|c|c|c|c|c|c|}
\hline Sandy grassland & & February 2009 & October 2011 & Adonis - F & p-value \\
\hline & October 2011 & 0.69 & & 1.85 & 0.069 \\
\hline & January 2012 & 0.53 & 0.65 & & \\
\hline \multirow[t]{3}{*}{ Stony grassland } & & February 2009 & October 2011 & Adonis - F & p-value \\
\hline & October 2011 & 0.47 & & 0.62 & 0.700 \\
\hline & January 2012 & 0.40 & 0.46 & & \\
\hline
\end{tabular}

their resilience capacity (i.e. implying a notion of both resistance and recovery sensu Hodgson et al., 2015) in the face of recurrent fires. These adaptive strategies include belowground meristematic and storage organs, thick corky bark, sclerophyllous leaves, fire resistant seeds, ability to resprout, and specialized flowering and fruiting phenologies (Bond and Keeley, 2005; Miranda et al., 2002; Oliveira et al., 2016).

Since the Cerrado flora, like many other savannas, has been assembled along with recurrent fires (Oliveira and Marquis, 2002; Simon et al., 2009), it seems essential to include fire in conservation management plans (Figueira et al., 2016; Overbeck et al., 2005; Ramos-Neto and Pivello, 2014; Ribeiro and Figueira, 2011). This requires the identification of adequate fire regimes (e.g. season of fire, frequency) as variation in fire regimes can induce changes in plant community composition or structure and/or in ecosystem functioning (Gorgone-Barbosa et al., 2015; Lehmann et al., 2008). By removing biomass, fire opens gaps necessary for germination and reduces competition for light and the dominance of few species, allowing the establishment and persistence of numerous other species (Fidelis et al., 2010; Grubb, 1977; Knox and Clarke, 2006; Overbeck et al., 2005). Fire ecology (i.e. fire effects and fire regimes) of some Cerrado ecosystems has been widely studied (Hoffmann, 1996; Hoffmann et al., 2012; Miranda et al., 2002; Mistry et al., 2005; Oliveras et al., 2012; Ramos-Neto and Pivello, 2014). However, such precise information is not available for campo rupestre grasslands. Understanding how fire impacts vegetation composition and structure can help to improve environment policies related to fire and thus future actions within reserves and national parks (Figueira et al., 2016; Ribeiro and Figueira, 2011).

Campo rupestre are part of the Cerrado biome and can be defined as a mosaic of herbaceous and savanna vegetations with shrubland on rocky outcrops (Fig. S1). This ecosystem establishes at altitudes above $900 \mathrm{~m}$ a.s.l., mainly along the Espinhaço range in eastern Brazil, (Silveira et al., 2016) and originally cov- ered 66,447 km² (Bitencourt et al., 2016; Silveira et al., 2016). Campo rupestre are species-rich ecosystems, established on shallow and oligotrophic, quartzite-derived soils with successive periods of water logging during the rainy season and water deficit during the dry season (Le Stradic et al., 2015a; Oliveira et al., 2015). Previous studies have already evaluated fire effects at the population-level for some species (Alves and Kolbek, 2010; Conceição et al., 2013; Conceição and Orr, 2012; de A.S. Ferreira and Conceição, 2012; Miola et al., 2010; Neves et al., 2011; Simon and Amaral, 2003). Overall, the effects of fire on campo rupestre grassland plant communities are still poorly understood (Figueira et al., 2016; Ribeiro and Figueira, 2011). To our knowledge only two studies described the effects of fire on campo rupestre plant communities. One of them, was based on a floristic survey complemented by plant collection and field observation (Kolbek and Alves, 2008) whereas the other one discussed the strategies of regeneration and investigated the composition and structure vegetation in a recently burnt area but did not present pre-fire data (Neves and Conceição, 2010). These studies concluded that vegetation cover and plant family composition in burnt campo rupestre recover rapidly after fire, mainly because many plant species have various adaptations to resprout from underground storage organs after fire. However, it appears that fire, in combination with grazing, can lead to invasion by an African grass (Melinis minutiflora) (Gorgone-Barbosa et al., 2016, 2015).

In this study, we aim to provide a precise assessment of the effects of fire on vegetation recovery and composition on both the short- and long-terms on the main herbaceous vegetation types: the sandy and stony grasslands. On the short-term, plant community composition was monitored before and two and five months after a wildfire to assess vegetation recovery. We used diachronic analyses of grasslands burnt at various dates to study the effects of fire on vegetation dynamics on the long-term (up to 25 years after the last fire). 

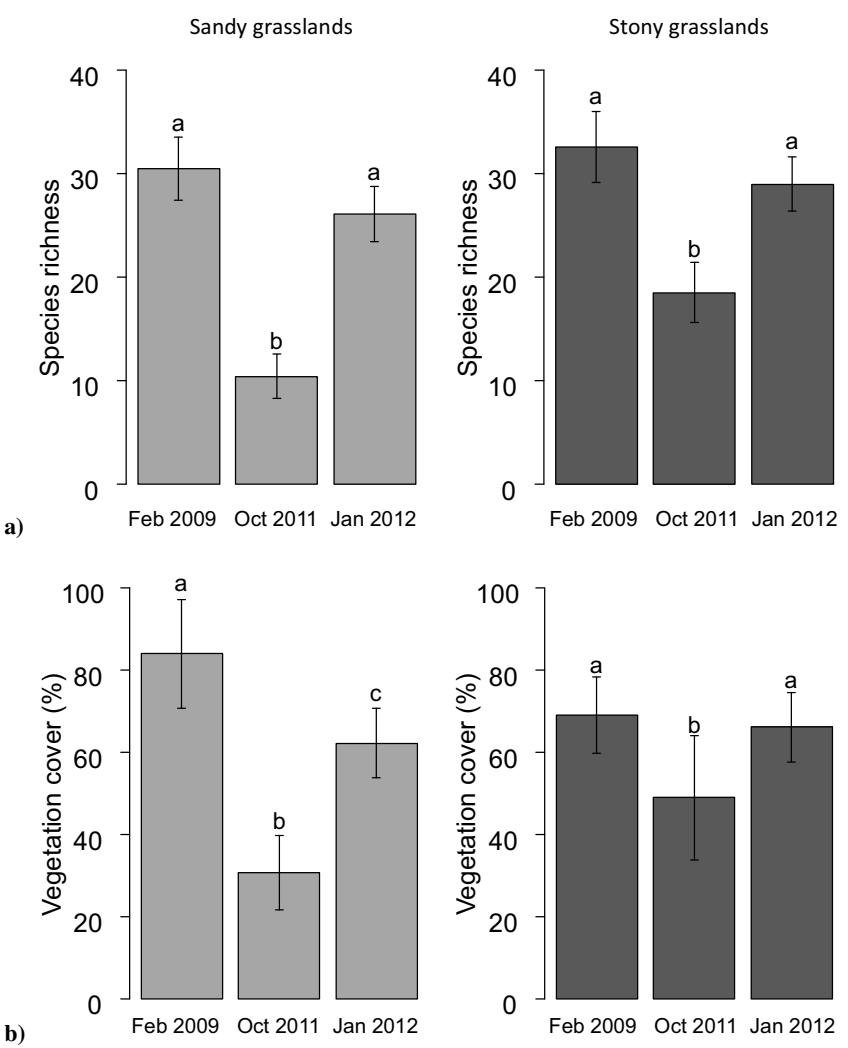

Fig. 1. Short-term impact of a wildfire on a) species richness (in $1 \mathrm{~m}^{2}$ ) and b) vegetation cover (cover percentage in $1 \mathrm{~m}^{2}$ ) in two types of campo rupestre vegetation at Serra do Cipó (Brazil): the sandy grasslands, represented with light grey bars, and the stony grasslands with dark grey bars. Quadrats were sampled before fire (Feb 2009), two months after fire (Oct 2011) and five months after fire (Jan 2012). Means \pm standard errors are shown. Bars with no letter in common are significantly different according to the glmer procedures and pairwise comparisons $(\mathrm{p}<0.05)$.

\section{Material and methods}

\subsection{Study sites}

The study was conducted in a campo rupestre located along and within the National Park of Serra do Cipó, about $100 \mathrm{~km}$ northeast of Belo Horizonte, southeastern Brazil (19 ${ }^{\circ} 15^{\prime}-25^{\prime} \mathrm{S}$ and $43^{\circ}$ $30^{\prime}-40^{\prime} \mathrm{W}$ ). The climate of the area is tropical altitudinal climate with an average annual rainfall of ca. $1622 \mathrm{~mm}$ mainly concentrated during the rainy season extending from November to April; the dry season extends from May to October (Madeira and Fernandes, 1999). The annual average temperature is $21.2^{\circ} \mathrm{C}$ (Madeira and Fernandes, 1999). All study sites are at altitudes between 1100 and $1420 \mathrm{~m}$ and $12 \mathrm{~km}$ separate the most distant sites. We studied the two dominant herbaceous vegetations of campo rupestre: the sandy grasslands (Sa) and the stony grasslands (St) (Fig. S1). These grasslands are subjected to frequent fires, leading to a mosaic of grassland patches burnt at different dates. According to Figueira et al. (2016) the peak frequency of fire return time in the Serra do Cipó National Park is seven years, indicating that the area is moderately susceptible to fire.

\subsection{Plant community composition and aboveground biomass sampling}

In order to obtain accurate data on short-term fire effects on plant communities, we monitored permanent plots in one stony and one sandy grassland site (Table 1 ), before and after a wildfire which occurred in August 2011 (sites are highlighted by * in Table 1 ). In each grassland site, vegetation surveys were carried out in ten $1-\mathrm{m}^{2}$ quadrats prior to fire, in February 2009, and twice after the fire, in October 2011 (i.e. two months after fire) and January 2012 (i.e. five months after fire).

To study long-term vegetation dynamics after fire, we sampled 12 stony and 12 sandy grassland sites between January and March 2012. Three replicates sites of four different times since last fire constituted the 12 sites of each vegetation type: (a) burnt less than a year ago, in 2011, (b) burnt 5 years ago, in 2007, (c) burnt 11 years

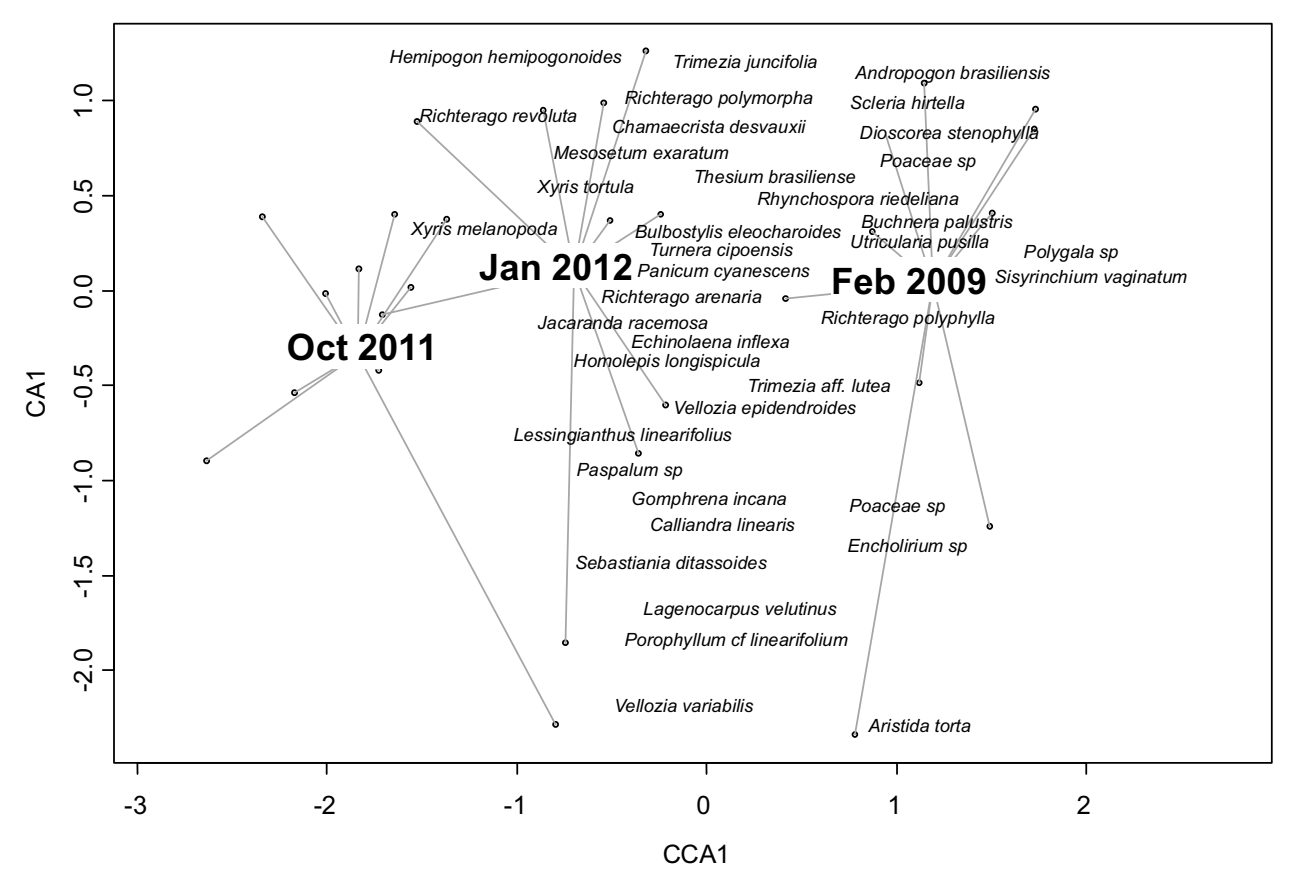

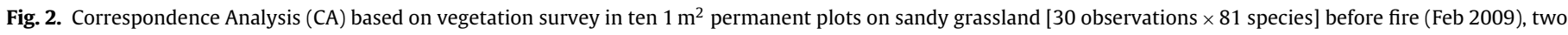






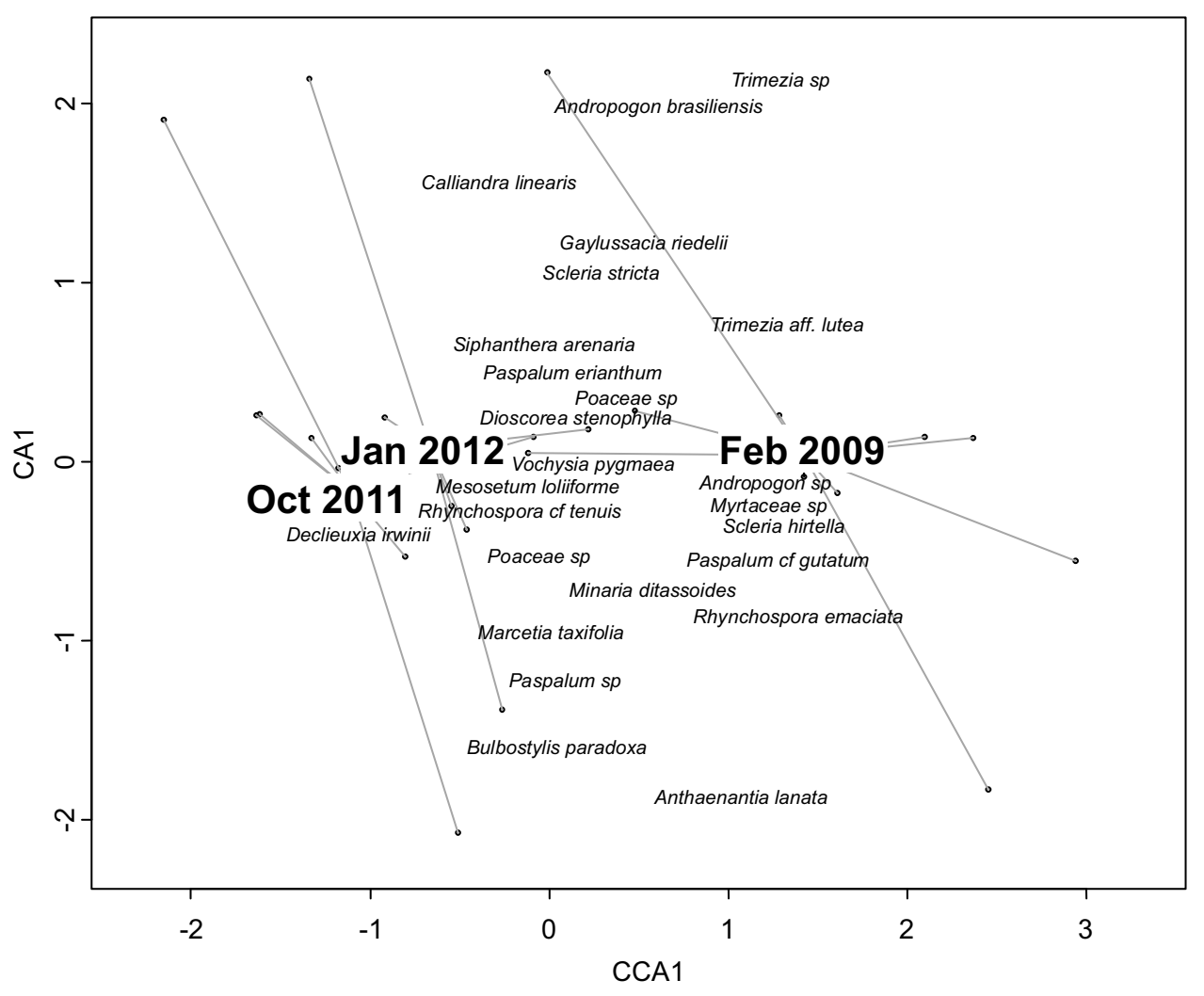

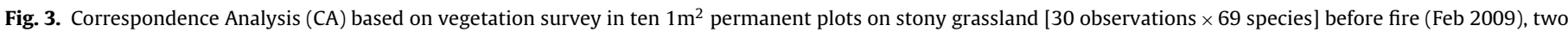



ago, in 2001 and (d) unburnt in the past 25 years, last burn dated at least in 1987 (Table 1). The sites were selected using a map of fire occurrence made from satellite images collected over the past 25 years and made available by the National Park of Serra do Cipó. On each site, ten $1-\mathrm{m}^{2}$ randomly placed quadrats were used to assess the plant community.

For both short-term and long term study, within each quadrat all angiosperm species were identified and their percent cover visually assessed based on the vertical projection of all aerial plant parts (Mueller-Dombois and Ellenberg, 1974).

Above-ground plant biomass was assessed in three $0.4 \times 0.4 \mathrm{~m}$ randomly placed quadrats in each site. All biomass above $5 \mathrm{~mm}$ of the ground was clipped and bagged separately for each quadrat. Living and dry biomass were separated in the laboratory. Biomass was weighed after oven-drying at $60^{\circ} \mathrm{C}$ for $48 \mathrm{~h}$.

\subsection{Statistical analyses}

Statistical analyses were conducted separately for the sandy grasslands (Sa) and the stony grasslands (St) considering the large difference in species composition between the two types of campo rupestre (Le Stradic et al., 2015a). All statistical analyses were performed in software R Version 3.2.1 (R Core Team, 2015), using stats, vegan (Oksanen et al., 2016) and lme4 (Bates et al., 2015) packages.

\subsubsection{Short-term effect of a fire passage}

We ran generalized linear mixed models (glmer in the R package lme4) with a Poisson error distribution, a log-link function and random effect for quadrats (Crawley, 2007), to assess variation of species richness before and after fire (prior to fire in February 2009, two months after fire in October 2011, and five months after fire in January 2012). For each grassland type, analyses of variance (ANOVA) for repeated measures and pairwise comparisons with $\mathrm{p}$ values adjustments according to Holm correction were used on the data of percentage cover over time, including quadrats as random effect. Percentage cover data were arcsine transformed to meet the assumptions of statistical analyses.

Dissimilarities between vegetation composition before and after fire were assessed using ANOVA-style analysis Adonis. Adonis (i.e. Multivariate ANOVA based on dissimilarities) is an analysis which implements a multivariate analysis of variances using distances matrices, to study the differences in group means and performs permutation tests to inspect the significances of the differences observed (Oksanen et al., 2016). Adonis function informs whether the groups consistently differ in their community composition. Adonis analyses were performed using Bray-Curtis dissimilarity to calculate distance matrices based on vegetation data (quadrat $\times$ species abundance matrices); it ranges from 0 and 1 and tends towards 1 as the dissimilarity between plant communities increases (Bray and Curtis, 1957).

Correspondence Analyses (CA) were performed to detect and visualize changes in plant community composition, structure, and recovery for each vegetation type. The two CAs (i.e. one for each vegetation type, with the matrix of species cover in sandy grasslands $=30$ observations $\times 81$ species and the matrix of stony grasslands $=30$ observations $\times 69$ species) were performed using data before fire (February 2009) and after fire (October 2011 and January 2012).

\subsubsection{Long-term fire effects}

Effects of time since last fire on mean species richness (number of species $/ \mathrm{m}^{2}$ ) and mean vegetation cover were assessed using Generalized Linear Models (glm) with a Poisson distribution for richness and a Gaussian distribution for vegetation cover. Time since last fire ((a) burnt less than a year ago (2011), (b) burnt 5 years ago (2007), (c) burnt 11 years ago (2001) and (d) unburnt 
in the past 25 years) was defined as the categorical explanatory variable.

Analyses of variance (ANOVA) and Tukey post-hoc tests were performed to compare biomass (i.e. total and dry biomass) according to time since last fire. Parametric conditions were tested for each grassland type using Shapiro-Wilk test of normality and Bartlett's test for homogeneity of variance. Whenever necessary, data were log-transformed to meet the assumptions of statistical analyses.

As previously explained, dissimilarities between vegetation composition over time since last fire were analyzed using ANOVAstyle analysis Adonis. We performed Constrained Correspondence Analyses (CCA, i.e. Correspondence Analyses with including a conditioning matrix) to detect and visualize changes in plant community composition and structure with time since last fire, including a conditioning matrix of altitude, the effect of which was removed (Oksanen, 2011). The two CCAs (i.e. one for each grassland type, with the matrix of species cover in sandy grasslands $=120$ observations $\times 229$ species and the matrix of stony grasslands $=120$ observations $\times 233$ species) were thus performed on the vegetation data collected in 2012 to assess differences between sites according to time since last fire (i.e. burnt less than a year ago (2011), burnt 5 years ago, burnt 10 years ago and unburnt in the past 25 years).

\section{Results}

\subsection{Short-term effect of fire}

Species richness and vegetation cover recovered quickly after fire. For both vegetation types, species richness showed a clear significant decrease just after fire from more than 30 species $/ \mathrm{m}^{2}$ on average in February 2009 and less than 20 species $/ \mathrm{m}^{2}$ in October 2001 (Fig. S1). However, five months after fire, in January 2012, species richness significantly increased to values close to pre-fire ones (glmer $\mathrm{z}_{\mathrm{Sa}}=59.69 \mathrm{p}_{\mathrm{Sa}}<0.001$; glmer $\mathrm{z}_{\mathrm{St}}=62.91$, $\mathrm{p}_{\mathrm{St}}<0.001$, Figs. 1a, S1). Vegetation cover was low two months after fire but increased significantly $\left(\mathrm{F}_{\mathrm{Sa}}=68.59\right.$, $\mathrm{p}_{\mathrm{Sa}}<0.001 ; \mathrm{F}_{\mathrm{St}}=19.88$, $\mathrm{p}_{\mathrm{St}}<0.001$, Figs. 1b, S1) to reach, five months after fire, values similar to pre-disturbance level on the stony grassland and values close to the pre-disturbance level on the sandy grassland (Figs. 1b, S1).

Five months after fire, vegetation composition and structure of both communities, did not differ from the pre-disturbance state, and returned to be very similar to the pre-disturbance state(Table 2 , Figs. 2 and 3, Table S1). No significant difference in terms of composition was found between plots sampled prior to fire, and two and five months after fire (Table 2). The CA revealed that the species composition of each quadrat of both grassland types sampled before fire and five months after fire were very similar (Figs. 2 and 3).

\subsection{Long-term vegetation dynamics after fire}

Species richness remained stable in sandy grasslands over 25 years ( $g l m$ procedure $z_{S a}=96.27, p=0.9$ ) but decreased with time since last fire on the stony grasslands ( $g l m$ procedure $\mathrm{z}_{\mathrm{St}}=133.04$, $\mathrm{p}<0.001$ ), with a higher species richness on recently burnt grasslands (i.e. less than 5 years ago, in 2011 and 2007) and lower species richness on grasslands burnt more than 11 years ago (Fig. 4a). Total vegetation cover strongly increased with time since last fire on sandy grasslands (glm procedure $\mathrm{F}_{\mathrm{Sa}}=97.27$, $\mathrm{p}<0.001$, Fig. $4 \mathrm{~b}$ ) while it slightly decreased on stony grasslands (glm procedure $\mathrm{F}_{\mathrm{St}}=34.76, \mathrm{p}<0.001$, Fig. 4b).

Species composition and community structure differed according to the date of the last fire (Table 3 ). For both vegetation types, species composition in the most recently burnt sites ( $<1$ year) and
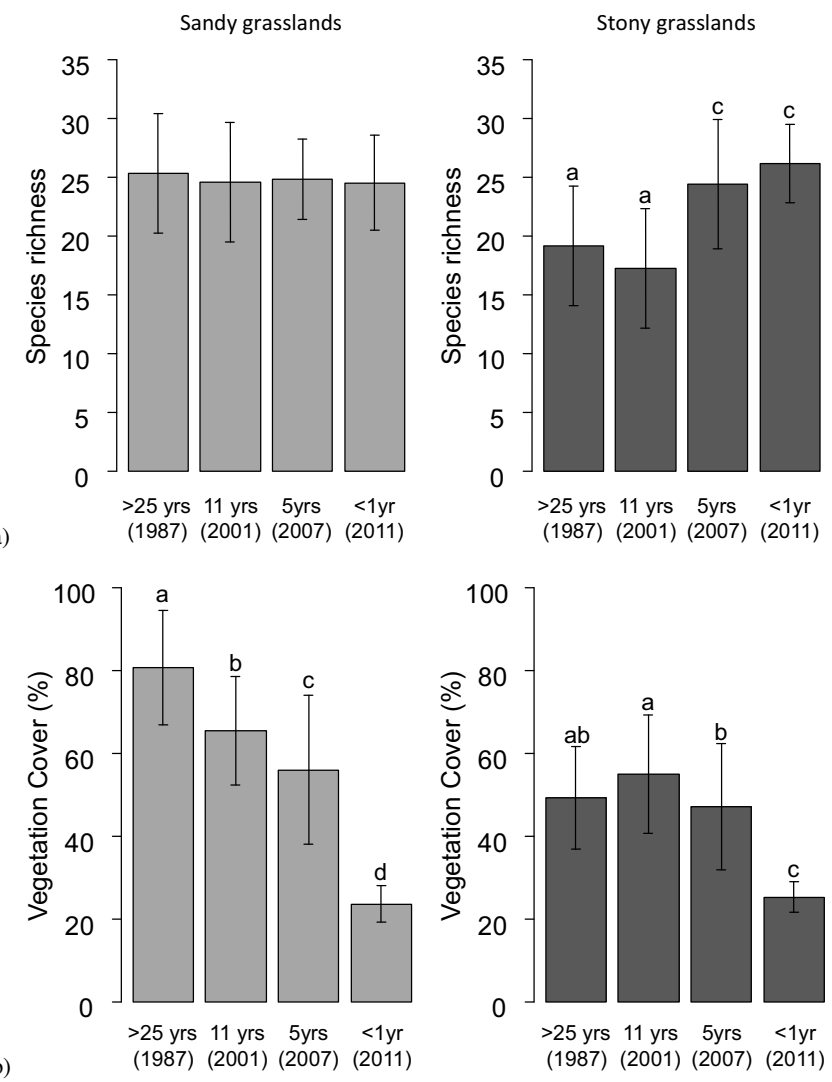

Fig. 4. Long-term impact of wildfires on a) species richness (in $1 \mathrm{~m}^{2}$ ) and b) vegetation cover (cover percentage in $1 \mathrm{~m}^{2}$ ). Two types of campo rupestre vegetation at Serra do Cipó (Brazil) are represented: the sandy grasslands, with light grey bars, and the stony grasslands with dark grey bars, according to time since last fire are: unburnt in the past 25 years (1987), burnt 11 years ago (2001), burnt 5 years ago (2007) and burnt less than one year (2011). Means \pm standard errors are shown. Bars with no letter in common are significantly different according to the glm procedures $(\mathrm{p}<0.05)$.

sites burnt less than 5 years before were more similar (Table 3 ). In both vegetation types, main differences in terms of vegetation composition were found between grasslands burnt 11 years prior to the study (2001) and grasslands unburnt in the past 25 years (Table 3).

CCA performed on sandy grassland data highlighted that recently burnt areas (2011 and 2007 i.e. burnt less than 5 years ago) were similar in terms of species composition (Fig. 5), and two of the three sites that were unburnt in the past 25 years were grouped together (Fig. 5, see also Table S2). On stony grasslands, only two of the three sites unburnt in the past 25 years showed a divergent composition compared to the other sites (Fig. 6). All other sites, although different in species composition, did not show divergent plant composition according to time since last fire (Fig. 6, see also Table S2).

There was almost twice more biomass in sandy grasslands than on stony grasslands in sites unburnt at last for 25 years (Fig. 7). Total biomass and dry biomass increased significantly with time since the last fire in both vegetation types (Fig. 7). While total and dry biomass increased gradually over time on stony grasslands $(\mathrm{F}=6.30, \mathrm{p}<0.001$ for total biomass, and $\mathrm{F}=5.69, \mathrm{p}<0.001$ for dry biomass; Fig. 7), on sandy grasslands, both the total and dry biomass remained stable for the first 11 years but doubled between 1987 and 2001, due to an important increase of dry biomass ( $F=12.74$, $\mathrm{p}<0.001$ for total biomass and $\mathrm{F}=13.37, \mathrm{p}<0.001$ for dry biomass; Fig. 7). 

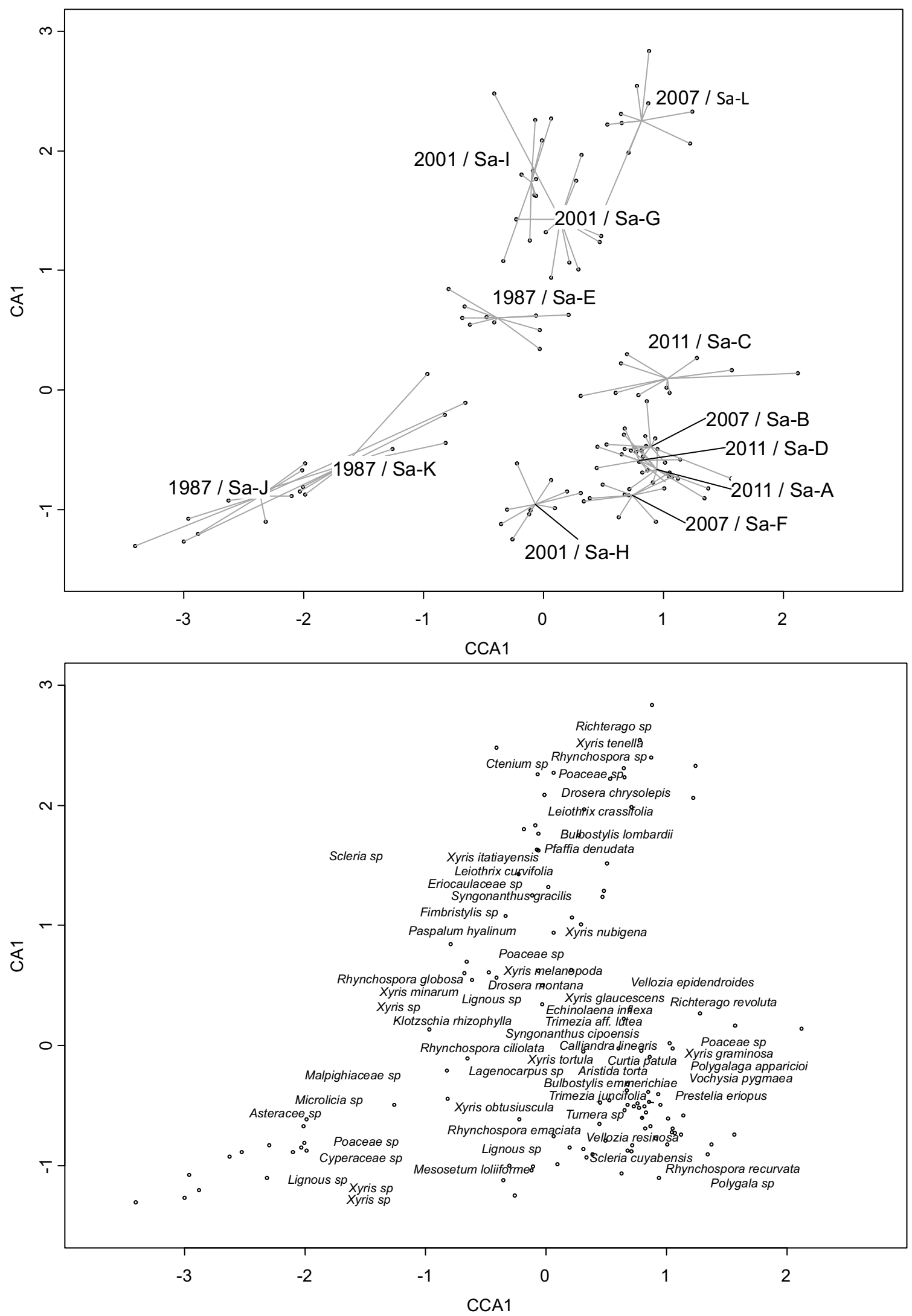

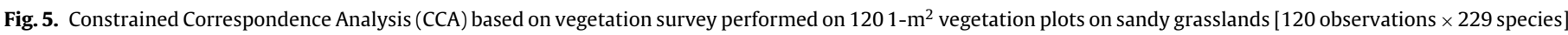

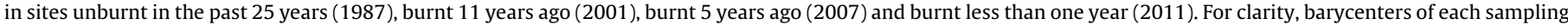

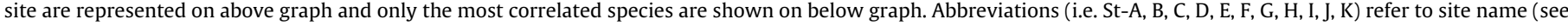
Table 1). 

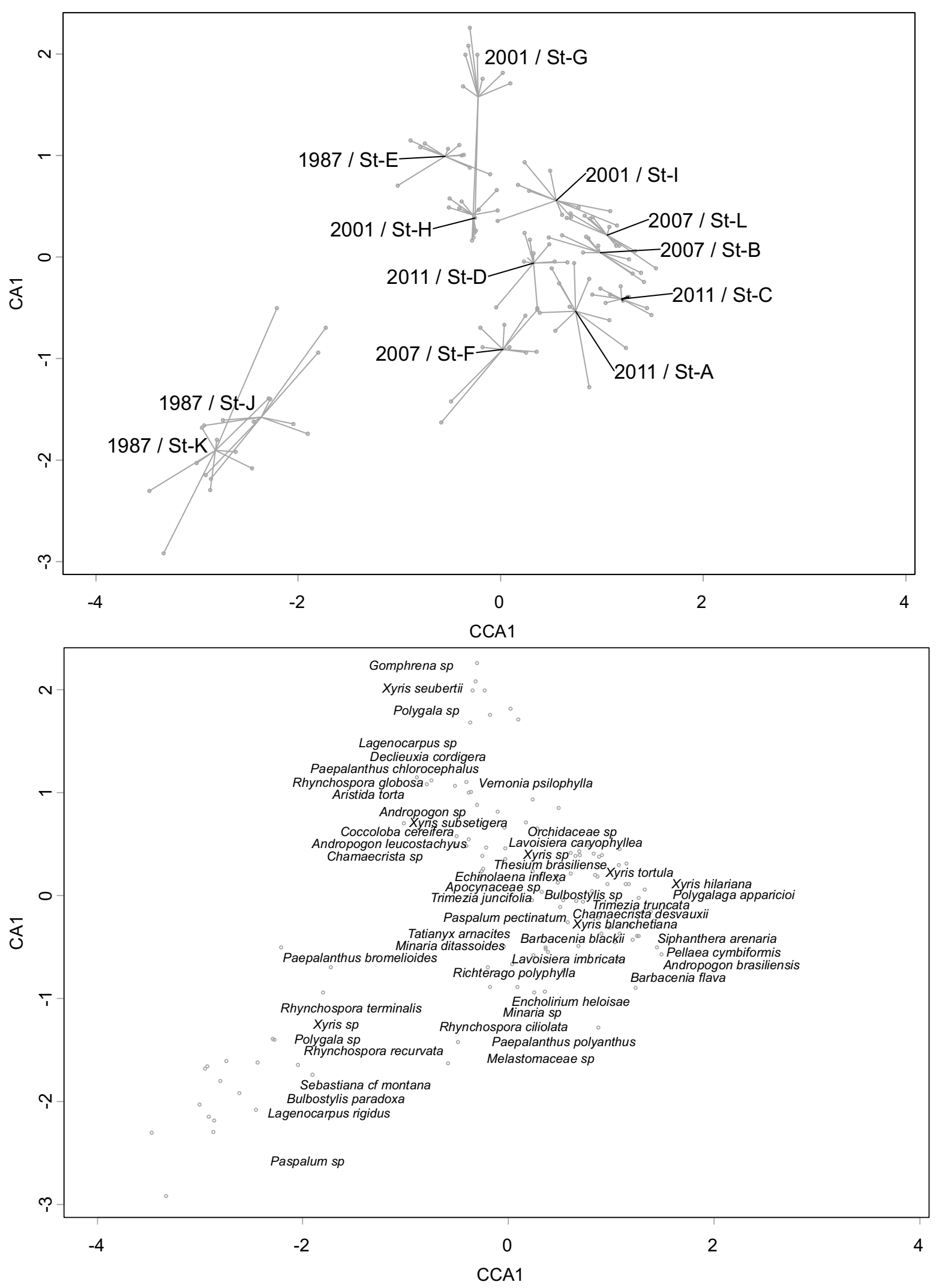

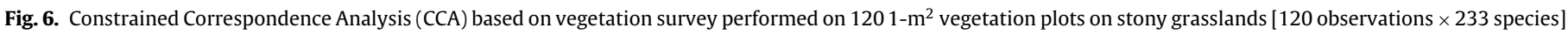

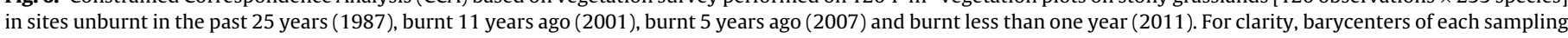

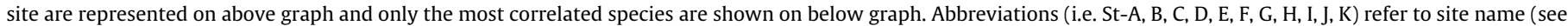
Table 1). 
Table 3

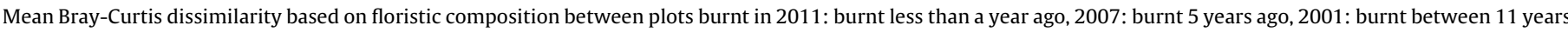

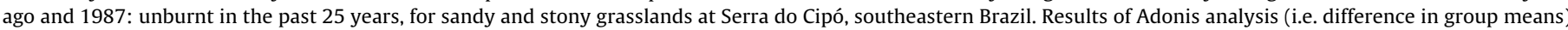
were based on Bray-Curtis dissimilarity (vegetation data).

\begin{tabular}{|c|c|c|c|c|c|c|}
\hline Sandy grasslands & & 1987 & 2001 & 2007 & Adonis - F & p-value \\
\hline & 2001 & 0.83 & & & 10.32 & 0.0049 \\
\hline & 2007 & 0.76 & 0.79 & & & $* *$ \\
\hline & 2011 & 0.71 & 0.79 & 0.68 & & \\
\hline \multirow[t]{4}{*}{ Stony grasslands } & & 1987 & 2001 & 2007 & Adonis - F & p-value \\
\hline & 2001 & 0.87 & & & 10.99 & 0.0049 \\
\hline & 2007 & 0.85 & 0.83 & & & $* *$ \\
\hline & 2011 & 0.83 & 0.84 & 0.76 & & \\
\hline
\end{tabular}
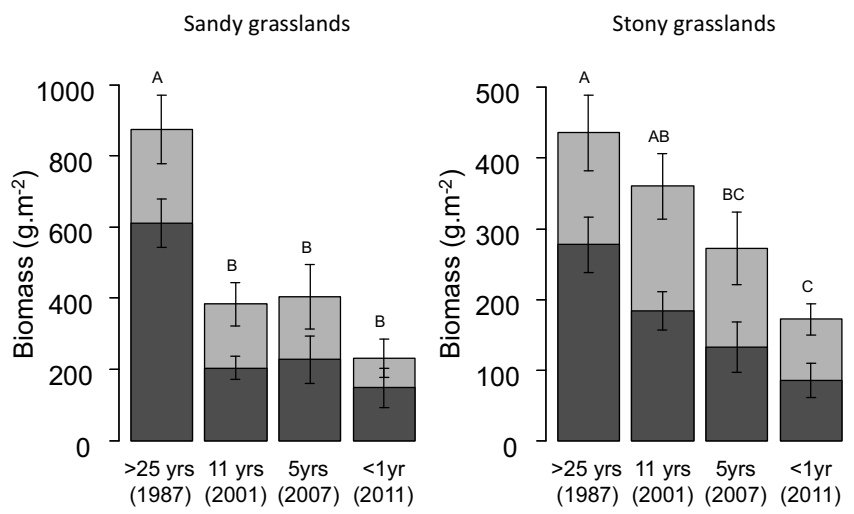

Fig. 7. Total plant biomass (light grey) and dry plant biomass (dark grey) in sandy and stony grasslands at Serra do Cipó (Brazil) in sites unburnt in the past 25 years (1987), burnt 11 years ago (2001), burnt 5 years ago (2007) and burnt less than one year (2011). Means \pm standard errors are shown. Results of Tukey post-hoc tests performed on total biomass are indicated with letters and were equal than Tukey post-hoc tests performed on dry biomass.

\section{Discussion}

The sandy and stony grasslands are two different habitat types within campo rupestre ecosystem (Le Stradic et al., 2015a), and both of them recover quickly, c.a. of five months, after wildfire in terms of species richness and community composition, which corroborates previous studies (Kolbek and Alves, 2008; Neves and Conceição, 2010). The high resumption capacity of both plant communities implies that most of the species are able to rapidly regenerate after fire. Vegetation cover on stony grasslands is naturally lower than that on sandy grasslands, because quartzitic rocks overlay a large share of the ground (Le Stradic et al., 2015a), that is why, in stony grasslands, vegetation reaches pre-fire cover values in only five months. On the other hand, vegetation cover is denser on sandy grasslands and, although our results show a delay for vegetation recovery in sandy grasslands, vegetation cover reaches values similar to pre-disturbance quite quickly as well.

Our study shows that fire is not related to an increase in species richness in campo rupestre, and community composition remains very similar before and after fire, contrary to subtropical grasslands in southern Brazil where fire can lead to a short-term increase in species richness, mainly through a reduction in plant competition and an increase in recruitment right after the fire (Overbeck et al., 2005). While some species seem to be slightly favored in the early post-fire environment, such as Poaceae or Cyperaceae which produce flowers and fruits in the weeks following a fire (personal observation), no post-fire colonization by opportunistic species has been observed. In many fire-prone environments, the recruitment processes of many species are restricted to the first post-fire year, as these processes are stimulated by factors related to fire (Bond et al., 1984; Bond and van Wilgen, 1996; Hobbs and Atkins, 1990; Knox and Clarke, 2006). In Australia or South Africa, fire regimes increase seedling emergence of shrubs (Bond et al., 1984; Bond, 1984; Hobbs and Atkins, 1990; Knox and Clarke, 2006). Although no study has dealt so far with recruitment processes after fire in campo rupestre, potential increase in recruitment of some campo rupestre species may not be due to fire-triggered germination (Fidelis et al., 2016; Le Stradic et al., 2015b) but instead because some species present fire-stimulated flowering and fruiting (Conceição and Orr, 2012; Fidelis and Blanco, 2014; Lamont and Downes, 2011; Le Stradic et al., 2015b).

In the present case, the regeneration of the original community appears mostly driven by the persistence of resprouters. In fire-prone environments, plant community assemblages contains species that are able 1) to resprout from any plant structure such as rhizomes, root buds, stem buds, etc. and persist via vegetative regeneration, i.e. resprouters, or 2) to thrive in and to recolonize a site through sexual reproduction and to persist at species level by seeds, i.e. seeders (Bell, 2001; Keeley and Fotheringham, 2000; Pausas et al., 2004). Whereas it has been usually neglected in favor of the 'regeneration niche', our results support the idea of the 'persistence niche' i.e. regeneration and persistence in situ is mainly due to species resprouting ability (Bond and Midgley, 2001). Resprouting ability is a key trait for persistence at the population level, enabling species to survive diverse disturbance regimes. It may result in a strong impact on community re-assembly, especially in fire-prone environments (Bond and Midgley, 2001; Clarke et al., 2013). Most of the species in sandy and stony grasslands are perennial species that resprout quickly after fire (Le Stradic et al., 2015a), which could explain the limited changes in terms of species richness observed in our plant communities; once established, perennial species do not necessary rely on seed germination to be maintained in the system, and therefore might be less impacted by biomass accumulation and shade.

No significant change in species richness over time was found in sandy grasslands, while only a slight decrease in species richness was observed in stony grasslands unburnt for more than 25 years. A decrease in species richness with time since last fire was expected (Bond and Keeley, 2005; Uys et al., 2004), especially because some plant species with high light requirements should be negatively affected by shade produced by increasing biomass. Competition generated by some dominant species and the accumulated biomass over time may limit the germination of annual species (Overbeck et al., 2005), as well as the persistence and growth of some herbaceous campo rupestre species that are not shade-tolerant. Stony grassland species might be more sensitive to competition for light because stony grasslands are naturally a more open vegetation, resulting in a negative correlation between species richness and biomass production (Overbeck et al., 2005).

While vegetation composition varied between the different study sites, including between recently burnt areas and unburnt areas, no clear pattern was observed in terms of fire impacts. It can result from the fact that vegetation composition analysis 
highlighted first the natural heterogeneity of campo rupestre plant communities (Le Stradic et al., 2015a) rather than the effect of fire on community composition. Campo rupestre are patchy plant communities under the control of local topography, nature of substrate, soil depth and fires (Fernandes, 2016; Le Stradic et al., 2015a; Neves and Conceição, 2010; Silveira et al., 2016). Campo rupestre are located on mountaintops and represent isolated islands where species endemism and narrow species endemism are common (Alves and Kolbek, 1994; Barbosa et al., 2015), leading to very high heterogeneity in plant community composition even at small spatial scale. Studies of long-term fire impacts on vegetation dynamics is therefore challenging. Natural heterogeneity of community composition and fire patchiness hampers greatly to untangle the effects of fire from the geographic localization of the plots. Long-term experimental studies using controlled burnings would be more appropriated to study the impact of fire on plant species composition in campo rupestre.

Similarly to our results, studies have shown that fire occurs due to fine fuel accumulation and many ignition sources (Figueira et al., 2016). As stony grasslands naturally present a higher level of bare ground compared to sandy grasslands (Le Stradic et al., 2015a), biomass accumulation in this type of vegetation is lower. Values of total biomass in campo rupestre varied between $200 \mathrm{~g} \mathrm{~m}^{-2}$ and $400 \mathrm{~g} \mathrm{~m}^{-2}$, which are similar to those found in campo sujo (i.e. open vegetation physiognomy) (Conceição and Pivello, 2011). However, without any fire for a long time period (i.e. >25 years), total biomass in sandy grasslands doubles, reaching values above $800 \mathrm{~g} \mathrm{~m}^{-2}$, which are similar to those in wet grasslands in Brazilian savanna without fire occurrence for four years (Fidelis et al., 2013). This implies that fire suppression over a long time period should lead to high biomass accumulation. Throughout the world, prescribed burning policy in fire-prone environments have resulted in a large accumulation of biomass, an increase of fuel load and in severe wildfires (Van Wilgen et al., 1998). In campo rupestre, the absence of sustainable fire management will probably lead to biological impoverishment (Figueira et al., 2016).

Whereas fire should be managed as a necessary conservation tool, prescribed burning is a matter of debate in Brazil (Durigan and Ratter, 2016; Figueira et al., 2016). Fire can be used to protect sensitive vegetation, some campo rupestre species (Conceição et al., 2013; Conceição and Orr, 2012) and to maintain community dynamics (Oliveras et al., 2012). However, fire can also lead to severe damages for some populations in case of inappropriate fire regimes (Silveira et al., 1999). Oliveras et al. (2012) suggested that an interval of at least 3-4 years between each burn can be a sustainable fire regime, allowing the reestablishment plant communities to a pre-burn condition of some Cerrado ecosystems. In the case of campo rupestre, further studies are needed to assess what fire regimes should be applied to maintain biodiversity and ecosystem services and what fire management strategy should be taken to avoid deleterious fires and conserve campo rupestre (but see Figueira et al., 2016). In order to guarantee conservation of their biodiversity and ecosystems services that have been severely threatened by fire suppression policy, the definition and implementation of a clear fire management policy is urgently necessary, especially in conservation units of cerrado and associated vegetation as the campo rupestre (Durigan and Ratter, 2016).

\section{Acknowledgments}

We thank the National Park of Serra do Cipó for having made their fire map available to us and two anonymous reviewers and Fernando A.O. Silveira for improving greatly the manuscript. This work was carried out with grants from the Conselho Nacional de Pesquisa (CNPq)[CNPq 561883/2010-6], Fundação de Amparo à Pesquisa do Estado de Minas Gerais (FAPEMIG), RTP CNRSCEMAGREF “Ingénierie Ecologique" [Ecological Engineering] SAVER - SAVanna Ecological Restoration, Natural Reserva Vellozia and the Ministère Français des affaires étrangères et européennes (EGIDE) [EGIDE 2009/657176K].

\section{Appendix A. Supplementary data}

Supplementary data associated with this article can be found, in the online version, at http://dx.doi.org/10.1016/j.flora.2016.12. 001.

\section{References}

Alves, R.J.V., Kolbek, J., 1994. Plant species endemism in savanna vegetation on table mountains (Campo Rupestre) in Brazil. Vegetatio 113, 125-139 http:// link.springer.com/article/10.1007/BF00044230.

Alves, R.J.V., Kolbek, J., 2010. Vegetation strategy of Vellozia crinita (Velloziaceae). Biologia (Bratisl) 65, 254-264, http://dx.doi.org/10.2478/s11756-010-0005-y.

Barbosa, N.P., de, U., Fernandes, G.W., Sanchez-Azofeifa, A., 2015. A relict species restricted to a quartzitic mountain in tropical America: an example of microrefugium? Acta Bot. Brasilica 29, 299-309, http://dx.doi.org/10.1590/ 0102-33062014abb3731.

Bates, D., Mächler, M., Bolker, B., Walker, S., 2015. Fitting linear mixed-effects models using lme4. J. Stat. Softw. 67, http://dx.doi.org/10.18637/jss.v067.i01.

Bell, D.T., 2001. Ecological response syndromes in the flora of southwestern Western Australia: fire resprouters versus reseeders. Bot. Rev. 67, 417-440, http://dx.doi.org/10.1007/BF02857891.

Bitencourt, C., Rapini, A., Santos Damascena, L., De Marco Junior, P., 2016. The worrying future of the endemic flora of a tropical mountain range under climate change. Flora - Morphol. Distrib. Funct. Ecol. Plants 218, 1-10, http:// dx.doi.org/10.1016/j.flora.2015.11.001.

Bond, W.J., Keeley, J.E., 2005. Fire as a global herbivore: the ecology and evolution of flammable ecosystems. Trends Ecol. Evol. 20, 387-394, http://dx.doi.org/10. 1016/j.tree.2005.04.025.

Bond, W.J., Midgley, J.J., 2001. Ecology of sprouting in woody plants: the persistence niche. Trends Ecol. Evol. 16, 45-51.

Bond, W., van Wilgen, B., 1996. Fire and Plants. Chapman \& Hall, London.

Bond, W., Vlok, J., Viviers, M., 1984. Variation in seedling recruitment of Cape Proteaceae after fire. J. Ecol. 72, 209-221.

Bond, W.J., Midgley, G.F., Woodward, F.I., Hoffman, M.T., Cowling, R.M., 2003. What controls South African vegetation - climate or fire? South Afr. J. Bot. 69, 79-91, http://dx.doi.org/10.1016/S0254-6299(15)30362-8.

Bond, W.J., 1984. Fire survival of Cape Proteaceae - influence of fire season and seed predators. Vegetation 56, 65-74.

Bray, J.R., Curtis, J.T., 1957. An ordination of the upland forest communities of southern Wisconsin. Ecol. Monogr. 27, 325-349, http://dx.doi.org/10.2307/ 1942268.

Bustamante, M.M.C., 2015. Política de clima negligencia o Cerrado -mais uma vez [WWW Document]. Obs. do Clima, URL http://www.observatoriodoclima.eco. br/politica-de-clima-negligencia-o-cerrado-mais-uma-vez/.

Carvalho, F.M.V., De Marco, P., Ferreira, L.G., 2009. The Cerrado into-pieces: habitat fragmentation as a function of landscape use in the savannas of central Brazil. Biol. Conserv. 142, 1392-1403, http://dx.doi.org/10.1016/j.biocon.2009.01.031.

Clarke, P.J., Lawes, M.J., Midgley, J.J., Lamont, B.B., Ojeda, F., Burrows, G.E., Enright, N.J., Knox, K.J.E., 2013. Resprouting as a key functional trait: how buds, protection and resources drive persistence after fire. New Phytol. 197, 19-35, http://dx.doi.org/10.1111/nph.12001.

Conceição, A.A., Orr, B.J., 2012. Post-fire flowering and fruiting in Vellozia sincorana, a caulescent rosette plant endemic to Northeast Brazil. Acta Bot. Brasilica 26, 94-100

Conceição, A.A., Pivello, V.R., 2011. Biomassa combustível em campo sujo no entorno do Parque Nacional da Chapada Diamantina, Bahia, Brasil. Biodiversidade Bras. 2, 146-160.

Conceição, A.A., Alencar, T.G., Souza, J.M., Moura, A.D.C., Silva, G.A., 2013. Massive post-fire flowering events in a tropical mountain region of Brazil: high episodic supply of floral resources. Acta Bot. Brasilica 27, 847-850, http://dx.doi.org/10. 1590/S0102-33062013000400025.

Coutinho, L.M., 1978. O conceito de cerrado. Rev. Bras. Botânica 1, 17-23.

Crawley, M.J., 2007. The R Book, ed. John Wiley, Chichester.

de A.S. Ferreira, M.M.A., Conceição, A.A., 2012. Alocação preferencial de recursos e morfologia de órgãos subterrâneos em plantas resistentes ao fogo em vegetação campestre. Sitientibus série Ciências Biológicas 12, 143-149.

Durigan, G., Ratter, J.A., 2016. The need for a consistent fire policy for Cerrado conservation. J. Appl. Ecol. 53, 11-15, http://dx.doi.org/10.1111/1365-2664. 12559.

Fernandes, G.W., 2016. Ecology and Conservation of Mountaintop Grasslands in Brazil. Springer International Publishing, Switzerland, http://dx.doi.org/10. 1007/978-3-319-29808-5.

Fidelis, A., Blanco, C., 2014. Does fire induce flowering in Brazilian subtropical grasslands? Appl. Veg. Sci. 17, 690-699, http://dx.doi.org/10.1111/avsc.12098. 
Fidelis, A., Müller, S.C., Pillar, V.D., Pfadenhauer, J., 2010. Population biology and regeneration of forbs and shrubs after fire in Brazilian Campos grasslands. Plant Ecol. 211, 107-117, http://dx.doi.org/10.1007/s11258-010-9776-z.

Fidelis, A., Lyra, M.F., di, S., Pivello, V.R., 2013. Above- and below-ground biomass and carbon dynamics in Brazilian Cerrado wet grasslands. J. Veg. Sci. 24, 356-364, http://dx.doi.org/10.1111/j. 1654-1103.2012.01465.x.

Fidelis, A., Daibes, L.F., Martins, A.R., 2016. To resist or to germinate? The effect of fire on legume seeds in Brazilian subtropical grasslands. Acta Bot. Brasilica 30, 147-151, http://dx.doi.org/10.1590/0102-33062015abb0187.

Figueira, J.E.C., Ribeiro, K.T., Ribeiro, M.C., Jacobi, C.M., França, H., de O, A.C., Conceição, A.A., Mourão, F.A., Souza, J.M., de K. Miranda, Miranda C.A., 2016. Fire in rupestrian grasslands: plant response and management. In: Fernandes, G.W. (Ed.), Ecology and Conservation of Mountaintop Grasslands in Brazil. Springer International Publishing, Switzerland, pp. 415-448.

Gorgone-Barbosa, E., Pivello, V.R., Bautista, S., Zupo, T., Rissi, M.N., Fidelis, A., 2015. How can an invasive grass affect fire behavior in a tropical savanna? A community and individual plant level approach. Biol. Invasions 17, 423-431, http://dx.doi.org/10.1007/s10530-014-0740-z.

Gorgone-Barbosa, E., Pivello, V.R., Baeza, M.J., Fidelis, A., 2016. Disturbance as a factor in breaking dormancy and enhancing invasiveness of African grasses in a Neotropical Savanna. Acta Bot. Brasilica 30, 131-137, http://dx.doi.org/10. 1590/0102-33062015abb0317.

Grubb, P.J., 1977. The maintenance of species-richness in plant communities: the importance of the regeneration niche. Biol. Rev. 52, 107-145, http://dx.doi.org/ 10.1111/j.1469-185X.1977.tb01347x.

Hobbs, R.J., Atkins, L., 1990. Fire-related dynamics of a Banksia woodland in south-western western Australia. Aust. J. Bot. 38, 97-110, http://dx.doi.org/10. 1071/BT9900097.

Hodgson, D., McDonald, J.L., Hosken, D.J., 2015. What do you mean, resilient? Trends Ecol. Trends Ecol. Evol. 30, 503-506, http://dx.doi.org/10.1016/j.tree. 2015.06.010.

Hoffmann, W.A., Geiger, E.L., Gotsch, S.G., Rossatto, D.R., Silva, L.C.R., Lau, O.L., Haridasan, M., Franco, A.C., 2012. Ecological thresholds at the savanna-forest boundary: how plant traits, resources and fire govern the distribution of tropical biomes. Ecol. Lett. 15, 759-768, http://dx.doi.org/10.1111/j. 1461 0248.2012.01789.x.

Hoffmann, W.A., 1996. The effects of fire and cover on seedling establishment in a Neotropical Savanna. J. Ecol. 84, 383-393, http://dx.doi.org/10.2307/2261200.

Keeley, J.E., Fotheringham, C.J., 2000. Role of fire in regeneration from seed. In: Fenner, M. (Ed.), Seeds: The Ecology of Regeneration in Plant Communities. CABI publishing, Wallingford, pp. 311-330.

Knox, K.J.E., Clarke, P.J., 2006. Fire season and intensity affect shrub recruitment in temperate sclerophyllous woodlands. Oecologia 149, 730-739, http://dx.doi. org/10.1007/s00442-006-0480-6.

Kolbek, J., Alves, J.R.V., 2008. Impacts of cattle, fire and wind in rocky savannas: southeastern Brazil. Acta Univ. Carolinae Environ. 22, 111-130.

Lamont, B.B., Downes, K.S., 2011. Fire-stimulated flowering among resprouters and geophytes in Australia and South Africa. Plant Ecol. 212, 2111-2125, http://dx. doi.org/10.1007/s11258-011-9987-y.

Le Stradic, S., Buisson, E., Fernandes, G.W., 2015a. Vegetation composition and structure of some Neotropical mountain grasslands in Brazil. J. Mt. Sci. 12, 864-877, http://dx.doi.org/10.1007/s11629-013-2866-3.

Le Stradic, S., Silveira, F.A.O., Buisson, E., Cazelles, K., Carvalho, V., Fernandes, G.W., 2015b. Diversity of germination strategies and seed dormancy in herbaceous species of campo rupestre grasslands. Austral Ecol. 40, 537-546, http://dx.doi. org/10.1111/aec.12221.

Lehmann, C.E.R., Prior, L.D., Williams, R.J., Bowman, D.M.J.S., 2008. Spatio-temporal trends in tree cover of a tropical mesic savanna are driven by landscape disturbance. J. Appl. Ecol. 45, 1304-1311, http://dx.doi.org/10.1111/j.13652664.2008.01496.x.

Madeira, J., Fernandes, G.W., 1999. Reproductive phenology of sympatric taxa of Chamaecrista (Leguminosae) in Serra do Cipo. J. Trop. Ecol. 15, 463-479.

McIntyre, S., Hobbs, R., 1999. A framework for conceptualizing human effects on landscapes and its relevance to management and research models. Conserv. Biol. 13, 1282-1292, http://dx.doi.org/10.1046/j. 1523-1739.1999.97509.x.

Miola, D.T.B., Correia, H.V.L., Fernandes, G.W., Negreiros, D., 2010. The effect of fire on phenology of Syagrus glaucescens Glaz. ex Becc. (Arecaceae). Neotrop. Biol. Conserv. 5, 146-153, http://dx.doi.org/10.4013/4759.

Miranda, H.S., Bustamante, M.M.C., Miranda, A.C., 2002. The fire factor. In: Oliveira, P.S., Marquis, R.J. (Eds.), The Cerrados of Brazil: Ecology and Natural History of a Neotropical Savanna. Columbia University Press, pp. 51-68.

Mistry, J., Berardi, A., Andrade, V., Krahô, T., Krahô, P., Leonardos, O., 2005. Indigenous fire management in the cerrado of Brazil: the case of the Krahô of Tocantíns. Hum. Ecol. 33, 365-386, http://dx.doi.org/10.1007/s10745-0054143-8.

Mistry, J., 2000. World Savannas: Ecology and Human Use. Routledge, New York.

Mittermeier, R.A., Turner, W.R., Larsen, F.W., Brooks, T.M., Gascon, C., 2011. Globa biodiversity conservation: the critical role of hotspots. In: Zachos, F.E., Habel, J.C. (Eds.), Biodiversity Hotspots: Distribution and Protection of Conservation Priority Areas. Springer Science \& Business Media, Berlin, pp. 3-22.
Mueller-Dombois, D., Ellenberg, H., 1974. Aims and Methods of Vegetation Ecology. John Wiley \& Sons, New York.

Neves, S.P.S., Conceição, A.A., 2010. Campo rupestre recém-queimado na Chapada Diamantina, Bahia, Brasil: plantas de rebrota e sementes, com espécies endêmicas na rocha. Acta Bot. Brasilica 24, 697-707.

Neves, A.C.O., Bedê, L.C., Martins, R.P., 2011. Revisão sobre os efeitos do fogo em Eriocaulaceae como subsídio para a sua conservação. Biodiversidade Bras. 2, 50-66.

Oksanen, J., Blanchet, F.G., Kindt, R., Legendre, P., Minchin, P.R., O’Hara, R.B., Simpson, G.L., Solymos, P., Wagner, M., Stevens, H.H., Wagner, H., 2016. Vegan: community ecology package [WWW Document]. R Packag. version 2. 3-3. URL http://cran.r-project.org/package=vegan.

Oksanen, J., 2011. Multivariate Analysis of Ecological Communities in R: vegan tutorial.

Oliveira, P.S., Marquis, R.J., 2002. The Cerrados of Brazil Ecology and Natural History of a Neotropical Savanna. Columbia University Press, New York.

Oliveira, R.S., Galvão, H.C., de Campos, M.C.R., Eller, C.B., Pearse, S.J., Lambers, H., 2015. Mineral nutrition of campos rupestres plant species on contrasting nutrient-impoverished soil types. New Phytol. 205, 1183-1194, http://dx.doi. org/10.1111/nph.13175.

Oliveira, R.S., Abrahão, A., Pereira, C., Teodoro, G.S., Brum, M., Alcantara, S., Lambers, H., 2016. Ecophysiology of campos rupestres plants. In: Fernandes, G.W. (Ed.), Ecology and Conservation of Mountaintop Grasslands in Brazil. Springer International Publishing, Switzerland, pp. 227-272.

Oliveras, I., Meirelles, S.T., Hirakuri, V.L., Freitas, C.R., Miranda, H.S., Pivello, V.R., 2012. Effects of fire regimes on herbaceous biomass and nutrient dynamics in the Brazilian savanna. Int. J. Wildl. Fire 22, 368-380, http://dx.doi.org/10.1071/ WF10136.

Overbeck, G.E., Müller, S.C., Pillar, V.D., Pfadenhauer, J., 2005. Fine-scale post-fire dynamics in southern Brazilian subtropical grassland. J. Veg. Sci. 16, 655-664, http://dx.doi.org/10.1658/1100-9233(2005)016[0655:FPDISB]2.0.CO;2.

Pausas, J.G., Bradstock, R.A., Keith, D.A., Keeley, J.E., 2004. The GCTE (Global change of terrestrial ecosystems) fire network, 2004. plant functional traits in relation to fire in crown-fire ecosystems. Ecology 85, 1085-1100.

R Core Team, 2015. R: A Language and Environment for Statistical Computing [WWW Document]. R Found. Stat. Comput, Austria, URL http://www.r-project. org/.

Ramos-Neto, M.B., Pivello, V.R., 2014. Lightning fires in a Brazilian savanna national park: rethinking management strategies. Environ. Manage. 26, 675-684, http://dx.doi.org/10.1007/s002670010124.

Ratnam, J., Bond, W.J., Fensham, R.J., Hoffmann, W.A., Archibald, S., Lehmann, C.E.R., Anderson, M.T., Higgins, S.I., Sankaran, M., 2011. When is a forest a savanna, and why does it matter? Glob. Ecol. Biogeogr. 20, 653-660, http://dx. doi.org/10.1111/j.1466-8238.2010.00634.x.

Ribeiro, M.C., Figueira, J.E.C., 2011. Uma abordagem histórica do fogo no parque nacional da Serra do Cipó, Minas Gerais -Brasil. Biodiversidade Bras. 1, 212-227.

Sankaran, M., Hanan, N.P., Scholes, R.J., Ratnam, J., Augustine, D.J., Cade, B.S., Gignoux, J., Higgins, S.I., Le Roux, X., Ludwig, F., Ardo, J., Banyikwa, F., Bronn, A., Bucini, G., Caylor, K.K., Coughenour, M.B., Diouf, A., Ekaya, W., Feral, C.J., February, E.C., Frost, P.G.H., Hiernaux, P., Hrabar, H., Metzger, K.L., Prins, H.H.T., Ringrose, S., Sea, W., Tews, J., Worden, J., Zambatis, N., 2005. Determinants of woody cover in African savannas. Nature 438, 846-849, http://dx.doi.org/10. 1038/nature04070.

Silveira, L., Rodrigues, F.H.G., Jácomo, A.T.A., Filho, J.A.D., 1999. Impact of wildfires on the megafaune of Emas National Park, central Brazil. Oryx 33, 108-114.

Silveira, F.A.O., Negreiros, D., Barbosa, N.P.U., Buisson, E., Carmo, F.F., Carstensen, D.W., Conceição, A.A., Cornelissen, T.G., Echternacht, L., Fernandes, G.W., Garcia, Q.S., Guerra, T.J., Jacobi, C.M., Lemos-Filho, J.P., Le Stradic, S., Morellato, L.P.C., Neves, F.S., Oliveira, R.S., Schaefer, C.E., Viana, P.L., Lambers, H., 2016. Ecology and evolution of plant diversity in the endangered campo rupestre: a neglected conservation priority. Plant Soil 403, 129-152, http://dx.doi.org/10. 1007/s11104-015-2637-8.

Simon, M.F., Amaral, M.F., 2003. Mimosa splendida Barneby (Mimosoideae, Leguminosae) rediscovered in Central Brazil: preliminary studies for conservation of a rare species. Braz. J. Bot. 26, 93-96, http://dx.doi.org/10. 1590/S0100-84042003000100010.

Simon, M.F., Grether, R., Queiroz, L.P., De Skema, C., Pennington, R.T., Hughes, C.E., 2009. Recent assembly of the Cerrado, a neotropical plant diversity hotspot, by in situ evolution of adaptations to fire. Proc. Natl. Acad. Sci. U. S. A. 106, 20359-20364.

Uys, R.G., Bond, W.J., Everson, T.M., 2004. The effect of different fire regimes on plant diversity in southern African grasslands. Biol. Conserv. 118, 489-499, http://dx.doi.org/10.1016/j.biocon.2003.09.024.

Van Wilgen, B.W., Biggs, H.C., Potgieter, A.L.F., 1998. Fire management and research in the Kruger National Park, with suggestions on the detection of thresholds of potential concern. Koedoe 41, 69-87, http://dx.doi.org/10.4102/ koedoe.v41i1.248. 